\title{
Concentration of Fluoride and Arsenic in Bottled Drinking Water in Durango City, Mexico
}

\author{
María Adriana Martínez-Prado ${ }^{{ }^{*}}$, María Elena Pérez-López ${ }^{2}$, María Guadalupe Vicencio-de la Rosa ${ }^{2}$, \\ Cecilia Corazón González-Nevarez ${ }^{1}$ \\ ${ }^{1}$ Chemical Engineering Department, Technological Institute of Durango (ITD), Durango, Mexico; ${ }^{2}$ National Polytechnic Institute \\ Interdisciplinary Research Center for Regional Integral Development at Durango (IPN-CIIDIR-DGO), Durango, Mexico. \\ Email: *adriana.martinez@orst.edu
}

Received October $2^{\text {nd }}, 2013$; revised November $1^{\text {st }}, 2013$; accepted November $26^{\text {th }}, 2013$

Copyright (c) 2013 María Adriana Martínez-Prado et al. This is an open access article distributed under the Creative Commons Attribution License, which permits unrestricted use, distribution, and reproduction in any medium, provided the original work is properly cited. In accordance of the Creative Commons Attribution License all Copyrights (C) 2013 are reserved for SCIRP and the owner of the intellectual property María Adriana Martínez-Prado et al. All Copyright (C) 2013 are guarded by law and by SCIRP as a guardian.

\begin{abstract}
Arsenic and fluoride are elements known to cause human health problems and it has been documented that both elements are found in high concentrations in the Guadiana Valley aquifer, in the state of Durango, Mexico. Since underground water is the source for potable water bottling companies commercialized in Durango City; such high concentrations reduced the quality of bottled water for human consumption according to NOM-041-SSA1-1993. Legislation establishes a maximum permissible limit (MPL) of $0.7 \mathrm{mg} / \mathrm{L}$ for fluoride and $0.025 \mathrm{mg} / \mathrm{L}$ for arsenic. In this research the main objective was to evaluate the quality of bottled water expended in Durango City with respect to the well from which water is extracted. Findings showed that the highest fluoride concentration was $5.86 \mathrm{mg} / \mathrm{L}$ (8.4 times MPL), with $100 \%$ of sampled brands exceeding the MPL (range: 1.09 to $5.86 \mathrm{mg} / \mathrm{L}$ ). On the other hand, for arsenic, the highest concentration was $0.076 \mathrm{mg} / \mathrm{L}$ (threefold), with $38 \%$ exceeding the MPL (range: 0.001 to $0.076 \mathrm{ppm}$ ). Statistical analysis showed significant differences only for fluoride, according to Fisher LSD (Least Significant Difference) test, with an $F$ value of 14.5 at a $p$ value of 0.0005 . According to the comparison between the quantified concentrations in bottled water and groundwater, it was found that groundwater was subjected to treatment; however, although a significant decrease in fluoride and arsenic concentration was observed, the removal processes used were not efficient to meet set standards.
\end{abstract}

Keywords: Arsenic; Bottled Water Quality; Fluoride; Guadiana Valley Aquifer; Groundwater

\section{Introduction}

Durango state is located in Northwest Mexico (Coordinates: $24^{\circ} 56^{\prime} 05^{\prime \prime} \mathrm{N} 104^{\circ} 54^{\prime} 43^{\prime \prime} \mathrm{W}$ ) and it stands at an altitude of $1880 \mathrm{~m}$. Durango City, with a population of 582,267 (2010), is the capital of Durango State and is located in the Guadiana Valley, in the southern central area of the state. Durango City is supplied with potable water from exploitation of Guadiana Valley aquifer through 1097 wells with an extraction volume of $148.31 \times 10^{6}$ $\mathrm{m}^{3} /$ year; National Water Commission in Durango reports that $100 \%$ of water demand is covered with groundwater $[1,2]$.

The Guadiana Valley aquifer is currently classified as

*Corresponding author. overexploited and fluoride and arsenic are present at much higher concentrations than the maximum permissible limits (MPL) established in NOM-127-SSA1-1994 [3]; however, their presence is mainly attributed to the strata geological composition [4-7].

Potable water bottling companies that are commercialized in the city extract water from groundwater wells, treat it before bottling, and must meet standards established by NOM-041-SSA1-1993 [8].

Maximum permissible limits (MPL) set by Mexican law varies depending on its use; NOM-127-SSA1-1994 [3] applies for groundwater $(0.025$ and $1.5 \mathrm{mg} / \mathrm{L}$, for arsenic and fluoride, respectively), whereas NOM-041SSA1-1993 [8] applies for bottled water (0.025 and 0.7 $\mathrm{mg} / \mathrm{L}$, for arsenic and fluoride, respectively). On the other 
hand, the World Health Organization (WHO) established $0.01 \mathrm{mg} / \mathrm{L}$ (or parts per million, ppm) for arsenic and 0.7 $\mathrm{mg} / \mathrm{L}$ for fluoride in water for human use and consumption, based on the fact that both of them could pose health damage. Research has been conducted about health problems caused by arsenic and fluoride; such as bones, skin and teeth damage from high fluoride exposure and cancer in some cases for arsenic [4,6,9-20].

The objective of this research was to evaluate the quality of bottled drinking water with respect to groundwater wells of Durango City, based on arsenic and fluoride concentration.

\section{Materials and Methods}

\subsection{Mapping and Sampling of Water Bottling Companies}

All water bottling companies of Durango City were inventoried, listed assigning sequential numbers instead of brand names (confidential status), categorized by sectors (North, South, West, and East), and located in a map using AutoCAD ${ }^{\circledR}$. Samples of all companies were collected twice with a time difference of six weeks. Sampling and preservation were performed according to the Standard Methods of Analysis; flasks were washed and rinsed with distilled water, for fluoride analysis; and for arsenic, flasks were washed with a $20 \%$ by volume nitric acid and hydrochloric acid solution plus the addition of concentrated nitric acid to reduce $\mathrm{pH}<2.0$ for preservation $[6,8,21]$.

\subsection{Fluoride and Arsenic Analysis}

Arsenic analysis was quantified with graphite furnace atomic absorption spectroscopy (GFAAS) established by standard methods [21]; whereas fluoride was determined using SPADNS spectrophotometric method [22].

\subsection{Statistical Analysis}

The differences between wells and companies, with respect to fluoride and arsenic content, and sectors (North, West, South, and East) were validated with a two-factor ANOVA (wells and companies); and with the LSD (Least Significant Differnce) Fisher test [6,7], to establish if the wells and companies had different contents or the same, all at an $\alpha=0.05$ using the Statistica software version $7^{\circledR}[23]$.

\section{Results and Discussion}

Thirty water bottling companies established in Durango City were inventoried; however, 6 run out of business, then only twenty-four were sampled twice: North (4), South (5), East (7), and West (8) [6].

\subsection{Quantification of Fluoride and Arsenic}

Calibration curves were developed for arsenic and fluoride. Concentration values were averaged with data gathered of the two samplings, by company and by sector. Results were evaluated comparing them to the maximum permissible limits (MPL) in drinking water according to the Mexican regulation (0.7 and 0.025 ppm, for fluoride and arsenic, respectively).

\subsection{Quality of Bottled Drinking Water}

The consumption of purified bottled water is a very common practice nowadays everywhere. In Durango City, many consumers buy bottled potable water because quality of water provided by municipal services is not trusted. In most cases companies offer containers of 20 liters (refillable) and only a minority offers bottles of less than or equal to 1 liter (non- refillable).

Results showed that the overall average concentration for fluoride was $2.67 \mathrm{mg} / \mathrm{L}$ with a range from 1.12 to $5.15 \mathrm{ppm}$. According to geographical location, it was found that the western sector (Figure 1) presented a greater incidence of fluoride, with an average of 3.29 ppm exceeding the MPL of $0.7 \mathrm{ppm}$ by almost fivefold. None of the average values in all four sectors were below the MPL, implying that $100 \%$ of the samples analyzed did not meet quality issues according to NOM-041SSA1-1993 with respect to the fluoride concentration. However, it is important to mention that fluoride concentration in bottled drinking water was statistically different from groundwater wells concentration; efficiency ranged from $20 \%$ to $70 \%$ by its decrease in concentration and from $75 \%$ to $87 \%$ with respect to the MPL (0.7 ppm), concentration was reduced in all cases except for one company (Table 1). Figure 1 shows average concentra-

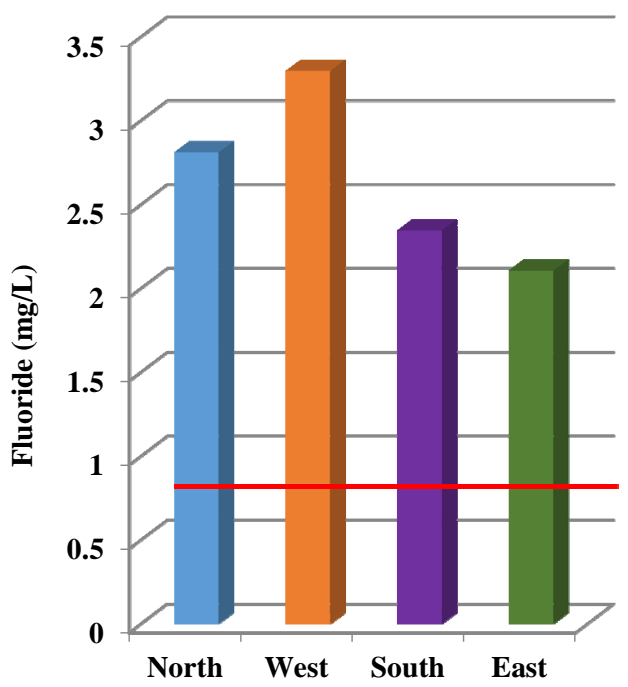

Figure 1. Average concentration of fluoride in water bottling companies by sector. Red line represents the MPL. 
Table 1. Fluoride and arsenic concentration in water bottling companies and well from which water is extracted.

\begin{tabular}{|c|c|c|c|c|c|c|c|c|c|}
\hline \multirow{2}{*}{$\begin{array}{c}\text { No. } \\
\text { (Sector) }\end{array}$} & \multicolumn{2}{|c|}{ Fluoride Concentration $(\mathrm{mg} / \mathrm{L})$} & \multicolumn{2}{|c|}{ Arsenic Concentration $(\mathrm{mg} / \mathrm{L})$} & \multirow{2}{*}{$\begin{array}{c}\text { No. } \\
\text { (Sector) }\end{array}$} & \multicolumn{2}{|c|}{ Fluoride Concentration $(\mathrm{mg} / \mathrm{L})$} & \multicolumn{2}{|c|}{ Arsenic Concentration $(\mathrm{mg} / \mathrm{L})$} \\
\hline & $\begin{array}{l}\text { Water Bottling } \\
\text { Company }\end{array}$ & $\begin{array}{c}\text { Groundwater } \\
\text { Well }\end{array}$ & $\begin{array}{c}\text { Water Bottling } \\
\text { Company }\end{array}$ & $\begin{array}{c}\text { Groundwater } \\
\text { Well }\end{array}$ & & $\begin{array}{c}\text { Water Bottling } \\
\text { Company }\end{array}$ & $\begin{array}{c}\text { Groundwater } \\
\text { Well }\end{array}$ & $\begin{array}{c}\text { Water Bottling } \\
\text { Company }\end{array}$ & $\begin{array}{c}\text { Groundwater } \\
\text { Well }\end{array}$ \\
\hline $7(\mathrm{~N})$ & 4.131 & $* * * *$ & 0.073 & **** & 5 (S) & 1.661 & 5.459 & 0.017 & 0.026 \\
\hline $13(\mathrm{~N})$ & 3.026 & 3.766 & 0.025 & 0.009 & $10(\mathrm{~S})$ & 2.187 & 4.902 & 0.060 & 0.037 \\
\hline $14(\mathrm{~N})$ & 2.053 & 2.809 & 0.012 & 0.034 & $11(\mathrm{~S})$ & 2.536 & 3.741 & 0.008 & 0.047 \\
\hline $30(\mathrm{~N})$ & 2.028 & 2.809 & 0.003 & 0.034 & $12(\mathrm{~S})$ & 3.493 & 4.902 & 0.001 & 0.038 \\
\hline $20(\mathrm{~W})$ & 2.754 & 5.888 & 0.032 & 0.037 & $15(\mathrm{~S})$ & 1.854 & 3.741 & 0.007 & 0.046 \\
\hline $21(\mathrm{~W})$ & 2.726 & 6.209 & 0.012 & 0.051 & $1(\mathrm{E})$ & 2.620 & 3.366 & 0.055 & 0.025 \\
\hline $22(\mathrm{~W})$ & 1.264 & 2.640 & 0.004 & 0.044 & $2(\mathrm{E})$ & 1.918 & 2.107 & 0.016 & 0.024 \\
\hline $23(\mathrm{~W})$ & 2.370 & 3.463 & 0.003 & 0.035 & $4(\mathrm{E})$ & 2.760 & 3.233 & 0.002 & 0.029 \\
\hline $24(W)$ & 1.936 & 3.463 & 0.005 & 0.035 & $6(\mathrm{E})$ & 1.276 & $* * * *$ & 0.003 & $* * * *$ \\
\hline $25(\mathrm{~W})$ & 5.724 & 3.589 & 0.054 & 0.049 & $9(\mathrm{E})$ & 2.312 & 4.684 & 0.076 & 0.021 \\
\hline $26(W)$ & 4.440 & 5.375 & 0.070 & 0.034 & $18(\mathrm{E})$ & 2.741 & 3.069 & 0.034 & 0.072 \\
\hline $27(\mathrm{~W})$ & 5.151 & 5.375 & 0.042 & 0.034 & 19 (E) & 1.119 & 4.752 & 0.001 & 0.011 \\
\hline
\end{tabular}

$\mathrm{N}=$ North; $\mathrm{S}=$ South; $\mathrm{W}=$ West; E = East; MPL for Fluoride = $0.7 \mathrm{mg} / \mathrm{L}$; MPL for Arsenic $=0.025 \mathrm{mg} / \mathrm{L}$; ${ }^{* * * *}$ Private well, not sampled.

tions by sector and Table 1 resumes concentrations for all water bottling companies and groundwater city wells.

For arsenic, the concentration ranged from detection limit (0.001) to $0.076 \mathrm{ppm}$; the overall average concentration was 0.0256 and the highest value found in bottled water in the city was $0.076 \mathrm{ppm}$ (eastern sector) 3 times the MPL. The resulting average concentrations by sector were slightly ( $6 \%$ to $13 \%)$ above the MPL $(0.025 \mathrm{mg} / \mathrm{L})$ for North, West and East sector and below MPL for South sector, and only $38 \%$ of the companies exceeded the MPL, see Table 1 and Figure 2 for results. As already mentioned, for arsenic, concentration in bottled drinking water was much lower than groundwater well; efficiency ranged from $14 \%$ to $97 \%$ by the reduction in its concentration and from $4 \%$ to $65 \%$ with respect to the MPL (0.025 ppm), concentrations in 5 companies were higher than groundwater well. If WHO standard (0.01 ppm) were considered, then $59 \%$ of the companies would not meet the MPL. In order to support information, random samples were sent for analysis to a certified laboratory and results were comparable to the ones obtained in this research.

\subsection{Isoconcentration Maps}

Surfer ${ }^{\circledR}$ software was used to elaborate isoconcentration maps with lines of equal concentration. It helps visualize the behavior of the concentration of fluoride and arsenic, of wells from which water is extracted by bottling companies. Figure 3 shows an isoconcentration map for fluoride in groundwater wells and location of companies. No isoconcentración map for arsenic is included because there were no significant differences between sectors, water bottling companies, and groundwater wells.

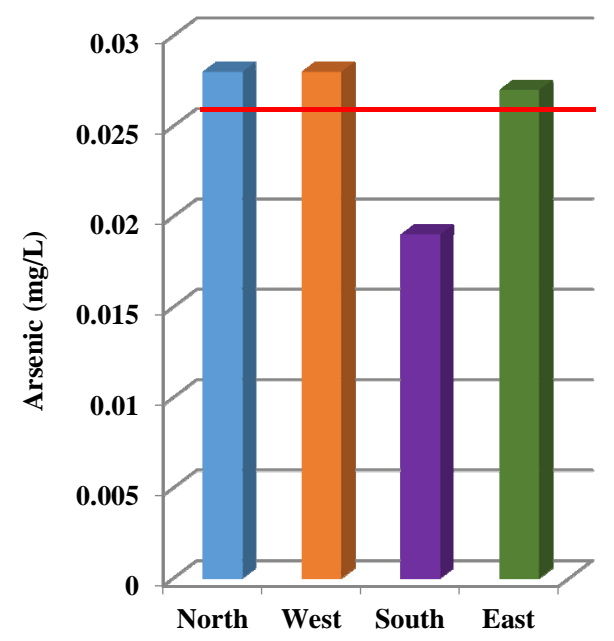

Figure 2. Average concentration of arsenic in water bottling companies by sector. Red line represents the MPL.

\subsection{Statistical Analysis: Water Quality Based on Fluoride and Arsenic Concentration}

Data of fluoride and arsenic concentrations gathered in this research was subjected to a statistical evaluation [6, 7] and was compared to concentration in Durango City groundwater wells, from which water is extracted prior to treatment and bottling process [4,7].

The ANOVA analysis showed significant differences for fluoride concentrations among bottling water companies (C) and groundwater wells (GW) with an F value of 14.5 at a p value of 0.0005 ; the mean fluoride concentration in $\mathrm{GW}$ was $4.1 \mathrm{mg} / \mathrm{L}$ versus $2.7 \mathrm{mg} / \mathrm{L}$ for $\mathrm{C}$; however, MPL was not met in any case. On the other hand, for arsenic, there were no significant differences between bottled water and groundwater wells. Figure 4 shows the 


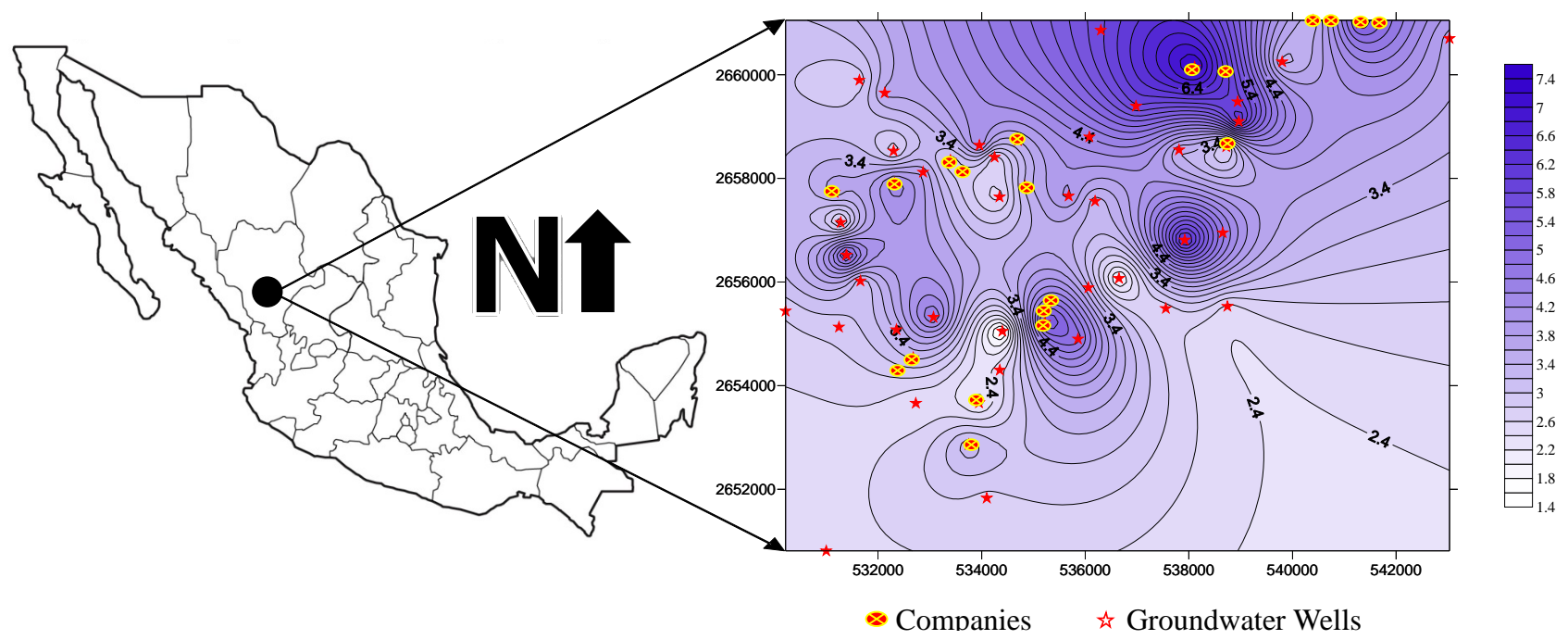

Figure 3. Fluoride isoconcentration (mg/L) map for groundwater wells in Durango City, Mexico.

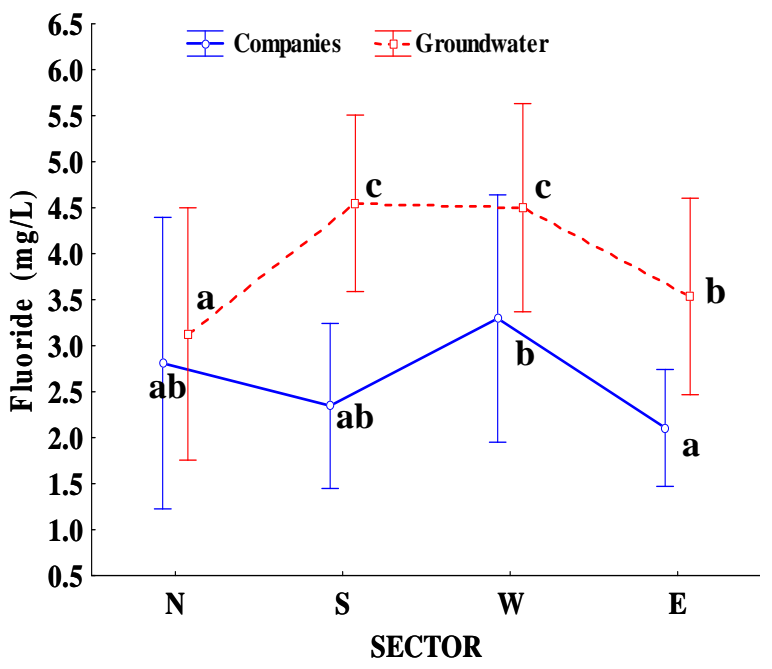

Figure 4. Fisher LSD test. Statistical analysis for fluoride concentration in water bottling companies versus groundwater wells, in Durango City, Mexico, from which water is extracted prior to treatment. Same letters meaning no differences between groups $(\alpha=0.05)$.

results for the statistical analysis for fluoride; which refers to the significant differences for fluoride concentration by sector (N, S, W and E) and source (C and GW) according to Fisher LSD (Least Significant Difference) test. Fisher's LSD is one of the existing methods for comparing treatment group means after the ANOVA null hypothesis of equal means has been rejected using the ANOVA F-test. Same letters equals to no differences between groups $(\alpha=0.05)$.

\section{Conclusions}

Results gathered in this research revealed deficiency in treatment, low removal efficiency and bad quality of potable bottled water, with respect to fluoride and arsenic content. Water source for water bottling companies established in Durango City comes from underground of Guadiana Valley aquifer. This aquifer is classified as overexploited and with high content of fluoride and arsenic due to its strata geological composition. All companies that commercialized bottled water in Durango City were tested to quantify fluoride and arsenic concentrations and compared to those concentrations present in groundwater wells.

For fluoride, $100 \%$ of the bottled water companies presented lower fluoride concentration compared to the groundwater wells. Comparing one of the cases, the well with the highest content had $5.46 \mathrm{ppm}$, whereas the concentration of bottled water extracted from the same well was $1.66 \mathrm{ppm}$. Efficiency ranged from $20 \%$ to $70 \%$ (decrease in concentration) and $75 \%$ to $87 \%$ with respect to the MPL $(0.7 \mathrm{ppm})$; only one company presented a higher concentration than the source, however, none of them met the MPL established ( $0.7 \mathrm{ppm})$.

For arsenic, $68 \%$ of the companies had a lower arsenic concentration compared to the underground water. In this case, the well with the highest arsenic concentration had $0.072 \mathrm{ppm}$ and the concentration found in the samples of the water bottling company, extracted from the same well, was $0.034 \mathrm{ppm}$. When determining efficiency, based on reduction in its concentration, range was from $14 \%$ to $97 \%$ and with respect to the MPL $(0.025 \mathrm{ppm})$ ranged from $4 \%$ to $65 \%$. Fifteen companies (62.5\%) met MPL; nine (37.5\%) did not meet MPL, where seven of them (26\%) presented a higher concentration than the source.

It is very clear that not all removal treatments used by water bottling companies were effective. In the case of fluoride, even though concentrations decreased substantially, none of the companies met the MPL. For arsenic removal treatments, $62.5 \%$ of the removal treatments used achieved the MPL. 
Statistical analysis showed significant differences only for fluoride, according to Fisher LSD test, with an F value of 14.5 at a p value of 0.0005 .

It is important to point out that the regulatory Agency of Water Resources, in Durango City, has made several attempts to solve this problem, to promote decrease concentration of fluoride and arsenic. Resources were allocated to the acquisition of small treatment plants for the removal of these compounds and were assigned to high concentration areas, without success due to lack of training in the handling of equipment and appropriately following the former proposal. A high percentage of the wells did not comply with standards representing latent health risk for adverse effects conferred by fluoride and arsenic. Action must be taken because chronic or acute health problems will manifest in the short or medium term, which represents high spending in the health sector.

\section{Acknowledgements}

This research was funded by the municipal government, Water Municipal Agency (AMD, Spanish acronym) Technological Institute of Durango (ITD, Spanish acronym), and National Polytechnic Institute-Interdisciplinary Research Center for the Local Integral Research, at Durango (IPN-CIIDIR-DGO, Spanish acronym). Masters Scholarship awarded by the National Council of Science and Technology (CONACyT, Spanish Acronym).

\section{REFERENCES}

[1] C. A. Scott, "The Water-Energy-Climate Nexus: Resources and Policy Outlook for Aquifers in Mexico," Water Resources Research, Vol. 47, No. 6, 2011, pp. 1-18. http://dx.doi.org/10.1029/2011WR010805

[2] Secretariat of Natural Resources and Environment, Government of the State of Durango, "Environmental and Ecological Management of Durango State and Annex of Ecological Management Model,” 2009. SRNyMA, Secretaría de Recursos Naturales y Medio Ambiente, Gobierno del Estado de Durango, “Ordenamiento Ecológico del Estado de Durango y Anexo Modelo de Ordenamiento Ecológico,” 2009.

http://www.semarnat.gob.mx/temas/ordenamientoecologi co/Paginas/ODecretados.aspx

[3] Secretariat of Environment and Natural Resources, "Modification to the NOM-127-SSA1-1994. Environmental Health. Water for Use and Human Consumption. Quality Permissible Limits and Treatments for Water Potabilization," Official Journal Federation, 2000. SEMARNAT, Secretariat de Medio Ambiente y Recursos Naturales, "Modificación a la Norma Oficial Mexicana NOM-127-SSA11994. Salud Ambiental. Agua para Uso y Consumo Humano. Límites Permisibles de Calidad y Tratamientos a que Debe Someterse el Agua para su Potabilización,” Diario Oficial de la Federación, 22 de Noviembre del 2000.

http://www.salud.gob.mx/unidades/cdi/nom/m127ssa14.h tml

[4] I. Flores-Montenegro, "Evaluation of Fluoride and Arsenic Concentration in Guadiana Valley Drinking Water and Removal Alternatives,” M.Sc. Thesis, Technological Institute of Durango, Durango, 1998. "Evaluación de las Concentraciones de Flúor y Arsénico en el Agua Potable del Valle del Guadiana y Alternativas de Remoción,” Tesis de Maestría, Instituto Tecnológico de Durango, México,1998.

[5] National Water Commission, General Technical Groundwater Management, "Determination of Water Availability in the Guadiana Valley Aquifer, State of Durango,” 2002. CNA, Comisión Nacional del Agua. Subdirección General Técnica Gerencia de Aguas Subterráneas, "Determinación de la Disponibilidad de Agua en el Acuífero Valle del Guadiana, Estado de Durango,” 30 de Abril del 2002. ftp://ftp.conagua.gob.mx/SISI1610100117809/DR_1003guadiana.pdf

[6] C. C. González-Nevarez, "Concentration Change of Arsenic and Fluoride in the Guadiana Valley Aquifer and Its Relationship to Static Level,” M.Sc. Thesis, Technological Institute of Durango, Durango, 2007. "Cambio de la Concentración de Arsénico y Flúor, en el Acuífero Valle del Guadiana, y su Relación con el Nivel Estático,” Tesis de Maestría, Instituto Tecnológico de Durango, México, 2007.

[7] M. A. Martínez-Prado, M. E. Pérez-López, I. VillanuevaFierro and C. C. González-Nevarez, "Behavior of Arsenic and Fluoride Concentration in Guadiana Valley Aquifer of Durango, Mexico," Journal of Environmental Protection Vol. 4, No. 12, 2013. Special Issue on Groundwater Pollution, in Press.

[8] Secretariat of Environment and Natural Resources, "NOM041-SSA1-1993. Bottled Purified Water. Sanitary Specifications," Official Journal Federation, 1995. SEMARNAT, Secretaría de Medio Ambiente y Recursos Naturales, "Norma Oficial Mexicana NOM-041-SSA1-1993. Bienes y Servicios. Agua Purificada Envasada. Especificaciones Sanitarias,” Diario Oficial de la Federación: 13 de Marzo de 1995.

http://200.77.231.100/work/normas/noms/kpronoman/p04 1ssa1.pdf

[9] L. M. Del Razo, M. A. Arellano and M. E. Cebrián, “The Oxidation Status of Arsenic in Well Water from a Chronic Arsenicism Area of Northern Mexico," Environmental Pollution, Vol. 64, No. 2, 1990, pp. 143-153. http://dx.doi.org/10.1016/0269-7491(90)90111-O

[10] G. A. Wasserman, et al., "Water Arsenic Exposure and Children's Intellectual Function in Araihazar, Bangladesh," Environmental Health Perspective, Vol. 112, No. 13, 2004, pp. 1329-1333. http://dx.doi.org/10.1289/ehp.6964

[11] A. Albores, M. E. Cebrian, I. Tellez and B. Valdez, "Comparative Study of Chronic Hydroarsenicism in Two Rural Communities in the Region Lagunera of Mexico," Boletín de la Oficina Sanitaria Panamericana, Vol. 86, No. 3, 1979, pp. 196-205.

[12] ATSDR, Agency for Toxic Substances and Disease Registry, “Toxicological Profile for Arsenic (Update),” US Department of Health and Human Services, Washington 
DC, 2007. http://www.atsdr.cdc.gov/toxprofiles/tp2.pdf

[13] E. Astolfi, A. Maccagno, J. C. García, R. Vaccaro and R. Stímola, "Relation between Arsenic in Drinking Water and Skin Cancer," Biological Trace Element Research Vol. 3, No. 2, 1981, pp. 133-143. http://dx.doi.org/10.1007/BF02990453

[14] M. E. Cebrian, A. Albores, M. Aguilar and E. Blakely, "Chronic Arsenic Poisoning in the North of Mexico," Human Toxicology, Vol. 2, No. 1, 1983, pp. 121-133. http://dx.doi.org/10.1177/096032718300200110

[15] A. H. Smith, E. O. Lingas and M. Rahman, "Contamination of Drinking Water by Arsenic in Bangladesh: A Public Health Emergency," Bulletin of the World Health Organization, Vol. 78, No. 9, 2000, pp. 1093-1103.

[16] M. T. Alarcón-Herrera, A. Martín Domínguez and I. R. Martín Domínguez, "Fluoride Concentration in Drinking Water: Its Relationship to Dental Fluorosis,” Proceedings of the 28th Inter-American Conference of Sanitary and Environmental Engineering, Cancun, 27-31 October 2002, pp. 1-5. “Concentración de Flúor en el Agua Potable: Su Relación con la Fluorosis Dental,” Memorias del XXVIII Congreso Interamericano de Ingeniería Sanitaria y Ambiental, Cancún, México, 27-31 Octubre 2002, pp. 1-5.

[17] S. Rivera, S. Godorecci, L. Orgel, E. Diaz, T. Fichs and M. I. Martin, "Fluorine: Potential Adverse Effects," The Revista Chilena de Pediatría, Vol. 64, No. 4, 1993, pp. 279-283. "Flúor: Potenciales Efectos Adversos". http://dx.doi.org/10.4067/S0370-41061993000400007

[18] ATSDR, Agency for Toxic Substances \& Disease Registry, "Toxicological Profile for Fluorides, Hydrogen Fluoride, and Fluorine,” US Department of Health and Human Services, Washington DC, 2003. http://www.atsdr.cdc.gov/toxprofiles/tp11.pdf

[19] L. E. Landin-Rodriguez, "Physicochemical Parameters and Concentration of Fluoride and Arsenic in Water from
Wells in the City of San Luis Potosi and Conurbated Area. Alternative Treatment: Fluoride and Arsenic Adsorption on $\mathrm{Al}_{2} \mathrm{O}_{3}$ Activated Interphase/Aqueous Solution,” M.Sc. Thesis, San Luis Potosi University, San Luis Potosi, 2006. "Parámetros Fisicoquímicos y Concentración de Flúor y Arsénico en el agua de los Pozos de la ciudad de San Luis Potosí y Zona Conurbada. Alternativa de Tratamiento: Adsorción de Flúor y Arsénico en la Interfase $\mathrm{Al}_{2} \mathrm{O}_{3}$ Activada/Solución Acuosa,” Tesis de Maestría, Universidad de San Luis Potosí, San Luis Potosí, 2006.

[20] M. Bocanegra-Salazar, "Health Risk Assessment for Exposure to Fluoride and Arsenic in Well Water for Consumption in High, Media, and Center Plateau Areas in the State of San Luis Potosi,” M.Sc. Thesis, San Luis Potosi University, San Luis Potosi, 2006. "Evaluación de Riesgo en Salud por la Exposición a Fluoruro y Arsénico en Agua de Pozo para Consumo de las Zonas Altiplano, Centro y Media del Estado de San Luis Potosí,” Tesis de Maestría, Universidad de San Luis Potosí, San Luis Potosí, 2006.

[21] APHA, "Standard Methods for the Examination of Water and Wastewater," 21st Edition, American Public Health Association, Washington DC, EUA, 2005.

[22] Secretariat of Economy, "NOM-AA-077-SCFI-2001. Water Analysis-Determination of Fluoride in Natural, Sewage and Treated Waste (Cancels: NMX-AA-077-1982),” 2001. SE, Secretaría de Economía, "NOM-AA-077-SCFI-2001. Análisis de Aguas-Determinación de Fluoruros en Aguas Naturales, Residuales y Residuales Tratadas (Cancela NMXAA-077-1982)," 2001. http://www.imta.gob.mx/cotennser/index.php?option=co m_content\&view=article\&id=94\&Itemid=84

[23] Statistica, “Data Analysis Software System,” Version $7^{\circledR}$, StatSoft, Inc., Tulsa, 2004. 